Key words synergetics, synergetic approach, pedagogical system, primary education, integration, educational process, components of the educational process, thematic and activity approaches to integration.

удк 373.3.017.4:316.47

Ольга Кривонос

Сумський державний педагогічний університет імені А. С. Макаренка ORCID ID 0000-0001-8076-3259 DOI 10.24139/2312-5993/2019.07/061-071

\title{
ВИХОВАННЯ ГРОМАДЯНСЬКИХ ЯКОСТЕЙ ШКОЛЯРІВ У НОВІЙ УКРАїНСЬКІЙ ШКОЛІ
}

Метою статті $\epsilon$ аналіз сучасних ефективних форм, методів, засобів виховання громадянських якостей школярів у контексті інноваційних перетворень сучасної української школи, зокрема: учнівське самоврядування, запровадження волонтерського руху в школі, залучення учнів до дитячих або молодіжних організацій та об'єднань, включення їх до всеукраїнських суспільних акцій, участь учнів у проектній діяльності, активні методи навчання на уроках. Представлено якості особистості, які формуються в прочесі громадянського виховання: любов до свого народу, краю, вітчизни, толерантність, демократизм, громадянська свідомість, громадянська гідність, громадянський обов'язок, громадянська відповідальність, громадянська мужність, працелюбність, повага до законів держави, чужої думки тощо.

Ключові слова: громадянське виховання, форми і методи громадянського виховання, учнівське самоврядування, волонтерський рух у школі, дитячі та молодіжні організації, проектна діяльність учнів.

Постановка проблеми. Інноваційні перетворення сучасної освіти України відповідно до Закону «Про освіту» та Концепції нової української школи передбачає формування сучасної компетентної особистості, яка здатна до життя в суспільстві та цивілізованої взаємодії з природою, має прагнення до самовдосконалення і навчання впродовж життя, готова до свідомого життєвого вибору, самореалізації, трудової діяльності та громадської активності (Закон «Про освіту», 2017).

Нами досліджується сучасний підхід до формування громадянський якостей школярів, що забезпечить їх громадську активність.

Адже зміцнити й розвинути демократичну правову державу, яка ввійшла би повноправним суб'єктом до європейської спільноти, можуть громадяни, які люблять свою країну, свій народ, готові самовіддано захищати й розбудовувати їі, які мають людську гідність, національну самосвідомість, гуманістичну моральність, знають свої права і свободи та вміють цивілізовано відстояти їх, сприяючи громадському миру і злагоді в суспільстві. 
Тому сьогодні важливим завданням українського суспільства на шляху до розбудови демократичної держави $€$ виховання громадянина, який бере активну участь у житті своєї громади. Саме тому школа не лише як освітня інституція, а й передусім як громадянський центр та традиційний духовний осередок місцевої спільноти має сприяти розвиткові демократичної політичної культури, формуванню громадянської компетентності, політико-правових знань та громадянської відповідальності молодого покоління.

Удосконалення будь-якого суспільства неможливе без систематичної й цілеспрямованої роботи з формування та розвитку особистості, особливо це стосується молодого покоління. Тому сучасна освіта в усьому світі повинна ставити проблему виховання громадянина на одне з перших місць, оскільки добре відомою є незаперечна істина: щоб демократія стала реальністю життя, потрібна зацікавленість людей у досягненні суспільно важливої мети і відповідальність за долю суспільства як за свою власну; потрібне сприяння зближенню інтересів особи, суспільства, держави й подолання або хоча б послаблення суперечностей між ними.

Аналіз актуальних досліджень. Різні аспекти проблем громадянського виховання на сучасному етапі розглядали такі дослідники, як М. Боришевський, І. Бех, О. Вишневський, Т. Дем'янюк, Б. Павленик, О. Сухомлинська, К. Чорна та ін., які переконливо доводять, що громадянське виховання вимагає постійного аналізу, науково-творчого обґрунтування, практичного забезпечення та розробки інноваційних технологій у зв'язку з модернізацією освіти в світлі Концепції нової української школи та новими вимогами суспільства. Все це вимагає пошуку нових педагогічних технологій, форм, методів та засобів у формуванні громадянських якостей учнів закладів загальної середньої освіти.

А. Дюркен зазначає, що як гасло звучить і сьогодні заклик С. Русової: «У наші часи бути гарним педагогом - це бути справжнім реформатором майбутнього життя України, бути апостолом Правди й Науки. Тільки великими зусиллями таких апостолів Україна матиме чесних діячівпатріотів, умілих практичних робітників, і соціально-об'єднану, інтелектуально-розвинену народну масу». Учитель, говорить С. Русова, завжди повинен пам'ятати, що його покликання не можна ні з чим поставити поруч, бо «хіба $€$ в кожного народу щось коштовніше, ніж душі його дітей, і хіба є обов'язки вищі за обов'язки виховати з них людей громадян?» (Дюркен, 2010, с. 17).

Проблематика громадянського виховання в умовах формування громадянського суспільства та модернізаційних освітніх процесів в Україні відображена в низці законодавчо-нормативних документів, прийнятих на державному рівні: Конституція України, Закон України «Про освіту», Закон України «Про загальну середню освіту», Закон України «Про громадянство 
України», Державна національна програма «Освіта: Україна XXI століття», Концепція «Нова українська школа» та Концепція громадянського виховання особистості в умовах розвитку української державності. У Національній доктрині розвитку освіти України в XXI столітті наголошено, що домінантною основою розвитку українського суспільства $є$ виховання «свідомого громадянина, патріота, набуття молоддю соціального досвіду, високої культури міжнаціональних взаємовідносин, формування в молоді потреби та вміння жити в громадянському суспільстві, духовності та фізичної досконалості».

Таким чином, громадянське виховання молоді має серйозне наукове і законодавче підґрунтя, що повинно бути використано в розробці сучасних підходів до розв'язання цієї проблеми.

Метою статті $€$ аналіз сучасних ефективних форм, методів, засобів виховання громадянських якостей школярів у контексті інноваційних перетворень сучасної української школи.

Методи дослідження. Щоб досягти мети дослідження було використано загальнонаукові методи: аналіз і синтез наукової філософської, психологічної, педагогічної літератури, що висвітлює різні підходи до визначення поняття «громадянське виховання», шляхи його здійснення, а також сучасних законодавчих нормативних документів, що визначають законодавчу базу предмету дослідження, емпіричний метод анкетування учнів шків щодо рівня сформованості громадянських якостей.

Виклад основного матеріалу. У вітчизняній педагогічній практиці громадянське виховання все частіше розуміється як система або модель шкільної освіти, яка наскрізь проходить не лише через навчальний процес у вузькому предметному значенні, але й у широкому значенні цього понятя $\epsilon$ надпредметною областю діяльності школи, що сприяє вихованню демократичних, громадських цінностей та поведінки всіх учасників освітнього процесу (Кривонос, 2018, с. 52). У цьому плані, як зазначає І. Бех, «громадянське виховання повинно стати серцевиною всієї діяльності школи як у процесі навчання, так і в позакласній роботі» (Бех, 2007, С. 5).

Крім того, його визначають як процес досягнення почуття єдності й політичної компетентності, поваги до свого та інших народів, прав, інтересів і цінностей, формування культури поведінки особистості, що ґрунтується на нормах моралі, законів, традицій.

Академік АПн України О. Сухомлинська у своїй статті «Громадянське виховання: спадщина у сучасність» наголошує, «що виховання громадянських якостей - це емоційно-почуттєве прилучення дітей до різних форм знання, розуміння, діяльності й поведінки, спрямованих на прояви громадянськості. До громадянських якостей належать: любов до свого народу, краю, вітчизни, толерантність, демократизм, громадянська свідомість, громадянська гідність, громадянський обов'язок, громадянська 
відповідальність, громадянська мужність, працелюбність, повага до законів держави, чужої думки тощо» (Сухомлинська, 2005, с. 3).

Мета громадянської освіти та виховання конкретизується через систему завдань (Кендзьор, 2005, с. 15-16): формування політичної та правової культури засобами громадянської освіти, яка забезпечує знання про політичні системи та владу на всіх рівнях суспільного життя, про закони та законодавчі системи; виховання поваги до Конституції України, законодавства, державної мови; розвиток критичного мислення, що забезпечує здатність усвідомлювати та відстоювати особисту позицію в тих чи інших питаннях, уміння находити нові ідеї та критично аналізувати проблеми, брати участь у дебатах, уміння переосмислювати дії та аргументи, передбачати можливі наслідки дій та вчинків; визнання й забезпечення в реальному житті прав людини як гуманістичної цінності та єдиної норми всіх людей без будь-яких дискримінацій, на чому будується відкрите, демократичне, громадянське суспільство; усвідомлення взаємозв'язку між ідеями індивідуальної свободи, прав людини та її громадянською відповідальністю; формування національної свідомості, належності до рідної землі, народу; визнання духовної єдності поколінь та спільності культурної спадщини; виховання почуття патріотизму, відданості у служінні Батьківщині; утвердження гуманістичної моралі та формування поваги до таких цінностей як свобода, рівність, справедливість; формування соціальної активності і професійної компетентності особистості на основі соціальних умінь: готовність до участі у процесах державотворення, здатність до спільного життя та співпраці у громадянському суспільстві, готовність взяти на себе відповідальність; здатність розв'язувати конфлікти згідно з демократичними принципами, здатність до самостійного життєвого вибору на основі гуманістичних цінностей; бути обізнаними у способах соціального захисту; формування інтеркультурного менталітету, сприятливості до культурного плюралізму, загальнолюдських цінностей, толерантного ставлення до інших культур і традицій; вироблення негативного ставлення до будь-яких форм насильства; активне попередження тенденцій до виявлення деструктивного націоналізму, проявів шовінізму, фашизму, месіанських налаштованостей.

Таким чином, громадянське виховання - це всеохоплююча категорія, що поєднує всі грані педагогічного процесу. Важливе місце в ньому посідає громадянська освіта - навчання, спрямоване на формування знань про права і обов'язки людини. Громадянська освіта тісно пов'язана 3 формуванням соціально-політичної компетентності особистості в суспільній сфері, яка передбачає, перш за все, політичну, правову й економічну освіченість й здатність керуватися відповідними знаннями в умовах кардинальної перебудови суспільства і реформи загальної середньої освіти в Україні. 
Сучасні завдання громадянського виховання вимагають зміни підходів в освіті як у змісті, так і в методиці викладання, що суттєво впливає і на зміну позиції вчителя, системи його професійної підготовки та підвищення кваліфікації.

Педагогам необхідна особлива підготовка в області громадянської освіти, орієнтована на реалії сучасного глобального світу, пошукові методи роботи з інформацією, усвідомленість і цілепокладання у вибудовуванні педагогічної діяльності, перехід від директивного до підтримуючого характеру викладання, проведення рефлексії з приводу досягнутих успіхів і зроблених помилок. В. Костів акцентує увагу, що шкільний учительпредметник, класний керівник має, насамперед, вирощувати в навчанні громадянську компетентність, формувати необхідні моральні якості. Звичайно, громадянська компетентність $€$ надпредметною, ключовою, і завдання щодо ії формування лежить у сфері відповідальності всієї шкільної системи виховання (Костів, 2011, с. 56).

Рада Європи розробила відповідний перелік умов формування громадянської компетентності на уроці, у школі, шкільному середовищі, серед них такі: активна участь учнів, педагогів і батьків у демократичному управлінні закладом освыти; демократизація методів навчання та виховання, відносин суб'єктів навчально-виховного процесу; поширення методів, орієнтованих на особистість учня, зокрема реалізація педагогічних проектів, що ґрунтуються на спільній колективній меті та співпраці учасників, які опікуються освітою $з$ питань демократичного громадянства (неурядові установи, підприємства, професійні організації); формування освітніх підходів, що тісно пов'язують теорію з практикою; залучення учнів до індивідуального та колективного оцінювання якості навчання; заохочення обмінів, зустрічей та партнерства між учнями та вчителями з різних закладів освіти для міжособистісного взаєморозуміння; поширення підходів і методів освіти, що сприяють вихованню у суб'єктів навчально-виховного процесу толерантності та поваги до культури і релігійної багатоманітності; зближення формальної і неформальної освіти; установлення відносини громадянського партнерства між школою і сім'єю, громадою, 3МІ (Івашковський, 2008, с. 38).

Н. Степанова підтверджує, що ініціатором відповідних заходів та напрямів діяльності мають бути, насамперед, заклади освіти, але головну роль у формуванні умов для розвитку громадянських компетентностей відіграють учителі. Адже саме вони реалізовують все це на практиці, створюють відповідну атмосферу (емоційно-психологічної захищеності, душевного комфорту), спрямовують начально-виховний процес, надаючи йому важливого значення у формуванні громадянських якостей особистості. (Степанова, 2014, с. 12).

Ефективність громадянської освіти значною мірою залежить від тих освітніх технологій та методів, які використовують педагоги у процесі 
навчання. Сучасний заклад освіти має чималий досвід викладання традиційними методами: лекції, семінари, диспути, бесіди, самостійна робота з підручником та періодикою, написання рефератів, учнівські наукові роботи. Потенціал цих методів із точки зору завдань громадянської освіти досить значний: вони дозволяють подати різноманітну інформацію, акцентувати увагу учнівської молоді на ключових аспектах теми, ознайомити з різними концепціями та підходами до проблеми, зробити загальні висновки. Проте, як зазначає О. Кучеренко, традиційні методи не орієнтовані на активну взаємодію школяра з учителем та однолітками, на самостійне і спільне прийняття рішень, що має бути вирішальною передумовою їх громадянської активності в майбутньому (Кучеренко, 2012, с. 41).

Тому пріоритетну роль у громадянській освіті мають відігравати активні методи, що стимулюють творчість, ініціативу, самостійне та критичне мислення й базуються на принципі багатосторонньої взаємодії. До активних методів та інноваційних форм належать різноманітні дискусії («гудіння бджіл», «сніжки», дискусія - симпозіум, «концентричне коло» та інші), ситуаційно-рольові ігри, ігри-драматизація, «мозкові атаки», інтелектуальні аукціони, метод аналізу проблемної ситуації, конкурси, тематичні вечори, читацькі конференції, години спілкування, тематичні акції, брейн-ринги, тренінги, учнівське самоврядування тощо.

Застосування наведених форм і методів громадянської освіти та виховання покликані формувати в особистості когнітивні та поведінкові норми, що включають у себе вміння міркувати, аналізувати, ставити запитання, шукати власні відповіді, критично та всебічно розглядати проблему, робити власні висновки, брати участь у громадському житті, здатність орієнтуватися й адаптуватися в нових соціальних умовах, захищати свої інтереси, поважати інтереси і права інших, самореалізуватися тощо.

І. Галицька переконує, що такі форми уроку, як урок-подорож, урокекспедиція, урок-дослідження, урок-інсценування, мультимедіа-урок, проблемний урок дозволять сформувати уявлення про основні питання, що входять до сфери громадянської освіти, підвести до розуміння нових громадянознавчих понять, активізувати пізнавальну активність учнів, сприяти формуванню громадянської компетентності (Галицька, 2005, с. 6).

Н. Аббас зазначає, що процес громадянського виховання особистості значною мірою зумовлюється змістовими характеристиками освітніх предметів, які сприяють оволодінню системою знань про людину та суспільство. Крім того, оволодіння системою знань формує здатність усвідомлювати місце своєї спільноти серед інших спільнот світу, норми міжнародного спілкування та взаємодії (Аббас, 2012, с. 38).

Однією з поширених та ефективних форм вростання школи в демократичні основи $\epsilon$ самоврядування. Найкращий спосіб пізнання демократії - це набуття власного досвіду щодо неї. Удосконалення системи 
самоврядування повинно розпочинатися зі створення Ради учнівського самоврядування, на чолі якої повинен стояти голова Ради з центрами управління. Мета такої форми виховання - включення всіх учнів у планування, організацію та виконання основних завдань загальношкільного об'єднання.

Самоврядування $\epsilon$ однією з важливих умов залучення учнів до громадянської діяльності. Самоврядування виховує ініціативу, активність, самостійність, самокритичність, відповідальність, організаторські здібності, формує вміння планувати, обирати головні напрями в роботі, чітко налагоджувати контроль і перевірку виконання, правильно розподіляти обов'язки, забезпечити координацію дій. Учні висловлюють власну думку, беруть участь у прийнятті рішень, що стосуються їх життя. Самоврядування в закладі загальної середньої освіти для учнів - справжня школа демократії, школа громадянського становлення підростаючого покоління.

Сучасним підходом до формування громадянських якостей школярів $€$ запровадження волонтерського руху, який із кожним роком набуває все більшої актуальності серед закладів загальної середньої освіти. Волонтерський рух - добровільна, доброзичлива, неприбуткова та вмотивована діяльність, яка має суспільно корисний характер. Волонтерство $\epsilon$ одним із компонентів моделі громадянсько-активної школи, метою якої $\epsilon$ налагодження партнерських стосунків між школою та всіма ресурсами, що існують у громаді. Сутність цього компонента полягає у створенні організованої системи, яка перетворює волонтерство на невід'ємну частину шкільного життя. Т. Лях стверджує, що ця система сприяє становленню людини як активного члена своєї громади, а для школи це добра можливість соціалізації дитини та ії̈ громадянського виховання (Лях, 2004, с. 75).

М. Боришевський досліджує ще одну активну форму роботи в напрямі формування громадянських якостей особистості - створення й залучення школярів до дитячих громадянських організацій, об'єднань, клубів створених як на території школи, так і поза ії межами.

Головне завдання вчителя - ознайомити учнів із цими організаціями, зацікавити їх у їхній діяльності, надати допомогу реалізувати себе в цих об'єднаннях, також педагог повинен провести бесіду з батьками дитини, обґрунтувати важливість, цілі й завдання цих організацій, залучити їх до співпраці з дитиною в цьому напрямі. За можливості перебирати досвід таких форм вияву громадянської позиції і створювати щось подібне у шкільному середовищі (Боришевський, 2007, с. 115).

Однією з форм навчання активності та виховання громадянської самосвідомості $€$ також проектна діяльність. Як зазначає О. Кожем'яка, методика проектування ґрунтується на безпосередньому застосуванні набутих знань, умінь та навичок під час практичної діяльності учня, отже, проходить всі форми навчальної діяльності - урочну, позаурочну, позашкільну та самоосвітню (Кожем'яка, 2014, с. 2). 
Метою соціального проектування - основного виду проектної діяльності для вчителя суспільних дисциплін - $є$ формування соціальних компетентностей через стимулювання у школярів інтересу до вирішення нагальних проблем суспільства. Задовольняючи цей інтерес, дитина бачить проблеми місцевої громади, досліджує їх та визнає своє ставлення; мотивує діяльність, відчуває їі соціальну значущість; установлює необхідні контакти; презентує результати діяльності та оцінює їі. Дуже важливо, що учні своїми діями розв'язують проблему. Учитель лише виконує функції консультанта, який не тисне авторитетом, а підказує, радить, коригує i спрямовує роботу.

3 метою виявлення рівня сформованості громадянської свідомості, належності до рідної землі, народу, почуття патріотизму, рівня соціальної активності, готовності до участі в державотворенні, нами було проведено анкетування 81 учня одинадцятого класу шести шкіл Сумської області. Анкетування виявило високий рівень сформованості таких громадянських якостей школярів, як гордість за свою країну, громадянська свідомість. На жаль, на низькому рівні знаходяться громадянська активність, школярі майже не беруть участі в усеукраїнському русі й реалізації громадянських проектів.

Отже, учителям шкіл, батькам, іншим соціальним інститутам необхідно прикладати більше зусиль для виховання справжніх громадян України.

Висновки та перспективи подальших наукових розвідок. Таким чином, проаналізовано виховні можливості інноваційних форм і методів громадянського виховання як під час уроків, так і в позаурочний час, зокрема: а) учнівське самоврядування, яке виховує ініціативу, активність, самостійність, відповідальність, формує вміння планувати, обирати головні напрями в роботі, правильно розподіляти обов'язки; б) запровадження волонтерського руху в школі, який забезпечує можливість соціалізації школяра, становлення учня як активного члена своєї громади, виховання моральних якостей особистості та включення до суспільно значимої діяльності; в) залучення учнів до дитячих або молодіжних організацій і об'єднань, включення їх до всеукраїнських суспільних акцій, що формує у школярів соціально-зрілу особистість, активну громадянську позицію, співпрацю з іншими школярами на всеукраїнському рівні; г) участь учнів у проектній діяльності, що забезпечує виховання їх громадянських якостей.

Перспективним може стати подальше дослідження ефективних форм і методів громадянського виховання в контексті інноваційних перетворень сучасної української школи.

\section{ЛITEPATУPA}

Аббас, Н. О. (2012). Роль та місце громадянської освіти в демократичному вихованні підростаючого покоління. Виховна робота в школі, 2, 37-38 (Abbas, N. О. (2012). The role and place of civic education in the democratic upbringing of the younger generation. Educational Work in School, 2, 37-38). 
Бех, І. Д., Чорна, К. І. (2007). Програма патріотичного виховання дітей та учнівської молоді. Шкільний світ, 13, 5 (Bekh, I. D., Chorna, K. I. (2007). Patriotic Education Program for Children and Student Youth. School World, 13, 5).

Боришевський, М. Й. (2007). Розвиток громадянської спрямованості особистості в юнацькому віці. К.: Педагогічна думка (Boryshevskyi, М. Ү. (2007). Development of civic orientation of the individual in adolescence. K.: Pedagogical thought).

Вишневський, О. І. (2005). На шляху реформ: актуальні питання сучасної української освіти та змісту виховання. Дрогобич: Коло (Vyshnevskyi, О. І. (2005). Towards reform: topical issues in contemporary Ukrainian education and content of upbringing. Drohobych: Circle).

Галицька, І. Ц. (2005). Інноваційні технології громадянського виховання. Виховна робота в школі, 5, 6-8 (Halytska, I. Ts. (2005). Innovative technologies of civic education. Educational Work in School, 5, 6-8).

Дюркен, А. М. (2010). Софія Русова - педагог, державний діяч, просвітитель: до 155річчя від дня народження: бібліографр. К.: Книга пам'яті України (Серія «Видатні педагоги світу». Вип. 6) (Diurken, A. М. (2010). Sophiia Rusova - teacher, statesman, educator: up to 155th anniversary: bibliography. K.: Memory book of Ukraine ("Outstanding Teachers of the World" Series. Issue 6).

Закон України «Про освіту» (2017) (Law of Ukraine "On Education" (2017). Retrieved from: https://zakon.rada.gov.ua/laws/show/1556-18.

Івашковський, В. В. (2008). Створення належних педагогічних умов - визначна складова процесу виховання громадянина. Рідна школа, 9, 36-40 (Ivashkovskyi, V. V. (2008). Creating proper pedagogical conditions - a crucial component of the process of educating a citizen. Native School, 9, 36-40).

Кендзьор, П. О. (2005). Основні напрями громадянського становлення учнівської молоді у вітчизняній системі освіти і виховання. Науково-методичний часопис. Доба з історичної та громадянської освіти, 1, 13-17 (Kendzior, P. О. (2005). The main directions of civic formation of student youth in the national system of education and upbringing. Scientific and methodological journal. Era in Historical and Civic Education, 1, 13-17).

Кожем'яка, О. Л. (2014). Виховний потенціал проектної діяльності. Історія та правознавство, позакласна робота, 3, 2-5 (Kozhemiaka, O. L. (2014). Educational potential of project activity. History and Jurisprudence, Extracurricular Work, 3, 2-5).

Концепція «Нова українська школа» (“New Ukrainian school" Concept) (2016). Retrieved from: https:// www.kmu.gov.ua/storage/app/media/reforms/ukrainska-shkolacompressed.pdf

Костів, В. А., Дерев'янко, Н. О. (2011). Формування громадянської культури особистості школяра: навч.-метод. посібник. К.: ТОВ «Праймдрук» (Kostiv, V. A., Derevianko, N. O. (2011). Formation of the civic culture of the student's personality: teaching manual. K.: "Primeprint").

Кривонос, О. Б. (2018). Виховання ціннісних орієнтацій сучасної молоді засобами масової інформації. Педагогічні науки: теорія, історія, інноваційні технології, 8 (82), 52-62 (Krivonos, O. B. (2018). Upbringing of value orientations of modern youth by means of mass media. Pedagogical sciences: theory, history, innovative technologies, 8 (82), 52-62).

Кучеренко, О. І. (2012). Громадянське виховання учнів в умовах інноваційної школи. Виховна робота в школі, 1, 41-44 (Kucherenko, O. І. (2012). Civic upbringing of students in an innovative school setting. Educational Work in School, 1, 41-44). 
Лях, Т. Л. (2004). Волонтерство як суспільний феномен. Луцьк: Волинський академічний дім (Liakh, T. L. (2004). Volunteering as a social phenomenon. Lutsk: Volyn Academic House).

Степанова, Н. М. (2014). Формування громадянської компетентності учнів загальноосвітніх закладів відповідно до вимог нових держаних освітніх стандартів. Черкаси (Stepanova, N. M. (2014). Formation of civic competence of pupils of secondary schools in accordance with the requirements of the new state educational standards. Cherkasy).

Сухомлинська, О. В. (2005). Громадянське виховання: спадщина і сучасність. Управління освітою, 24, 3-5 (Sukhomlynska, O. V. (2005). Civic education: heritage and modernity. Education Management, 24, 3-5).

\section{PEЗЮME}

Кривонос Ольга. Воспитание гражданских качеств школьников в новой украинской школе.

Целью статьи является анализ современных эфрфективных форм, методов, средств воспитания гражданских качеств школьников в контексте инновационных преобразований современной украинской школы, а именно: ученическое самоуправление, внедрение волонтерского движения в школе, привлечение учащихся в детские или молодёжные организации и объединения, подключение их $к$ всеукраинским общественным акциям, участие учеников в проектной деятельности, активные методы обучения на уроках. Представлена характеристика качеств личности, которые формируются в прочессе гражданского воспитания: любовь к своему народу, краю, отечеству, толерантность, демократизм, гражданская сознательность, гражданская честь, гражданская обязанность, уважение к законам страны, чужой мысли и другие.

Ключевые слова: гражданское воспитание, формы и методы гражданского воспитания, ученическое самоуправление, волонтерское движение в школе, детские и молодежные организации, проектная деятельность учащихся.

\section{SUMMARY}

Krivonos Olha Upbringing of schoolchildren's civic qualities in new Ukrainian school.

The purpose of the article is to analyze modern effective forms, methods and means of citizenship education of schoolchildren in the context of innovative transformations of the modern Ukrainian school. Citizenship education is understood as a system or model of school education that goes through not only the educational process in a narrow subjective sense, but in the broad sense of the term is above the subject area of the school, which promotes upbringing of democratic, public values and behavior of all the participants of the educational process. It provides for upbringing of a conscious citizen, a patriot, acquisition of social experience by young people, high culture of interethnic relations, formation in youth of needs and ability to live in civil society, spirituality and physical excellence.

Educational opportunities of innovative forms and methods of citizenship education both during lessons and extracurricular activities are analyzed, in particular: student selfgovernment, which fosters initiative, activity, independence, responsibility, forms ability to plan, choose the main directions in work, correctly distribute; introducing a volunteer movement at school that provides the opportunity for socialization of the student, developing a student as an active member of his community, nurturing moral qualities of the individual and engaging him in socially significant activities; involving students in children's or youth organizations and associations, including them in all-Ukrainian public actions, which form 
students as socially mature personalities, develop their active civic position, ensure cooperation with other students at the all-Ukrainian level; participation of students in project activities that ensure upbringing of their civic qualities. The design methodology is based on the direct application of the acquired knowledge and skills in the practical activity of the student, therefore, he passes all forms of educational activity - lesson, extracurricular, outof-school and self-educational.

Key words citizenship education, forms and methods of citizenship education, student self-government, volunteer movement at school, children's and youth organizations, students' project activities.

УДК 378.937

\author{
Наталія Лавриченко \\ Глухівський національний педагогічний \\ університет імені Олександра Довженка \\ ORCID ID 0000-0003-0776-7362 \\ DOI 10.24139/2312-5993/2019.07/071-080
}

\title{
РОЗВИВАТИ МУЗИЧНУ ОБДАРОВАНІСТЬ
}

Феномен музичної обдарованості розглянуто в сукупності генетичних передумов, головних чинників розвитку, структурних складників та особливостей реалізації в життєвій практиці. Проаналізовано специфічні ознаки й характеристики музично обдарованої особистості, зокрема в контексті інших видів обдарованості, мультиобдарованості.

Ключові слова: обдарована дитина, музичні здібності, навчання, розвиток.

Постановка проблеми. Природу музичної обдарованості найчастіше розуміють як таку, що має генетичну зумовленість, а музичні здібності вважають природним даром. На підтвердження наводять приклади династій, яких порівняно більше серед музично обдарованих людей - Бахи, Вагнери, Моцарти, Ріхтери, Ростроповичі, Щендрини тощо. «Якщо й існує галузь людських досягнень, у якій важливо мати певні генетичні задатки, то це музика» - констатує винахідник множинного інтелекту Г. Гарднер (Гарднер, 2007, с. 164).

Разом із тим, чимало дослідників музичної обдарованості не тільки не заперечують, а навпаки, підкреслюють важливість навчання й виховання, цілеспрямованого формування необхідних для музики людських якостей і рис характеру, а також роль шансу, сприятливих умов і обставин. У реальному житті успадковані й набуті здібності, зокрема й музичні, настільки тісно переплетені, що їх складно диференціювати, тим паче ранжувати. Адже генотип як сукупність генетично зумовлених здібностей визначає музичну обдарованість здебільшого як потенційну, а от реальних обрисів вона набуває в процесі взаємодії індивіда з оточенням - соціальним, культурним, мистецьким. 